\title{
\begin{tabular}{l|l|l} 
Jurnal Eksplorasi Akuntansi & $\begin{array}{l}\text { ISSN : 2656-3649 (Online) } \\
\text { Vol. 1, No 1, Seri A, Februari 2019, Hal 64-77 }\end{array}$ & http//jea.ppj.unp.ac.id/index.php/jea/issue/view/1
\end{tabular}
}

\section{ANALISIS IMPLEMENTASI GOOD GOVERNANCE PADA PENGELOLAAN ANGGARAN PENDAPATAN DAN BELANJA NAGARI}

\author{
Gustiman Candra ${ }^{1}$, Herlina Helmy ${ }^{2}$, Nayang Helmayunita ${ }^{3}$ \\ ${ }^{1)}$ Alumni Jurusan Akuntansi Fakultas Ekonomi Universitas Negeri Padang \\ ${ }^{2,3)}$ Jurusan Akuntansi Fakultas Ekonomi Universitas Negeri Padang \\ *Korespondensi: gustimanc@gmail.com
}

\begin{abstract}
This research aims to find out how to manage the Nagari Revenue and Expenditure Budget (APBNagari) in Koto Nan Tigo Utara Surantih and Koto Nan Tigo Selatan Surantih, Sutera Subdistrict, Pesisir Selatan District and find out how good governance is implemented in the management of the Nagari Income and Expenditure Budget (APBNagari) in Koto Nan Tigo Utara Surantih and Koto Nan Tigo Selatan Surantih, Sutera District, Pesisir Selatan District. To achieve these objectives, qualitative research methods are used. Data collection techniques are carried out by interview, observation and documentation. The results of the study showed: (1) Management of APB Nagari in Koto Nan Tigo Utara Surantih and Koto Nan Tigo Selatan Surantih based on Permendagri Number 20 of 2018 concerning Village Financial Management there were problems at the planning stage. Nagari Koto Nan Tigo Selatan Surantih late in the Determination of RPJM Nagari and APB Nagari and Nagari Koto Nan Tigo Utara Surantih was only late in the APB Nagari determination. The late stipulation of the APB Nagari was due to the issuance of regulations from the regency to the Nagari. The stages of administration, reporting and accountability are in accordance with Permendagri Number 20 Year 2018 concerning Village Financial Management. (2) Implementation of Good Governance principles in the management of APB Nagari on the nagari of Koto Nan Tigo Utara Surantih and Koto Nan Tigo Selatan Surantih has been carried out quite well by Nagari government.
\end{abstract}

Keywords: Good Governance; Nagari Revenue and Expenditure Budget

How to cite (APA $6^{\text {th }}$ style)

Candra, G., Helmy, H., \& Helmayunita, N. (2019). Analisis Implementasi Good Governance pada Pengelolaan Anggaran Pendapatan dan Belanja Nagari. Jurnal Eksplorasi Akuntansi, 1(1) Seri A, 64-77.

\section{PENDAHULUAN}

Desa atau yang disebut nama lain adalah kesatuan masyarakat hukum yang memiliki batasbatas wilayah yang berwenang untuk mengatur dan mengurus kepentingan masyarakat setempat, berdasarkan asal-usul dan adat istiadat setempat yang diakui dan dihormati dalam sistem Pemerintah Negara Republik Indonesia, hal ini terdapat dalam PP Nomor 72 tahun 2005 tentang desa. Kewenangan Desa dalam mengatur dan mengurus rumah tangga desa dimulai dari dikeluarkannya Undang-Undang Nomor 8 tahun 2005 tentang perubahan atas 
Undang-undang Nomor 32 tahun 2004 tentang Pemerintah Daerah mengakui adanya otonomi yang dimiliki oleh desa dan kepada desa dapat diberikan penugasan ataupun pendelegasian dari pemerintah ataupun pemerintah daerah untuk melaksanakan urusan pemerintah tertentu. Pemerintah desa dalam melaksanakan kewenangan tersebut memiliki sumber pembiayaan, hal ini terdapat dalam PP Nomor 72 tahun 2005 tentang desa bahwa sumber keuangan desa berasal dari Pendapatan Asli Desa (PADesa), bagi hasil pajak, dan retribusi kabupaten atau Alokasi Dana Desa (ADD).

Penyelenggaraan pemerintah desa diharapkan dapat mendorong peningkatan kapasitas dan kemandirian desa untuk mencapai kesejahteraan masyarakat. Pemerintahan Indonesia yang dipimpin oleh presiden Joko Widodo-Jusuf Kalla tahun 2014-2019 pembangunan desa menjadi prioritas dalam agenda pemerintahannya, hal ini berdasarkan dalam Nawacita ketiga yang berbunyi, "Membangun Indonesia yang dimulai dari pinggiran dengan memperkuat daerah dan desa dalam kerangka Negara Kesatuan Republik Indonesia". Komitmen pemerintah dalam membangun Indonesia dari pinggiran ditandai dengan dikeluarkannya Undang-undang Nomor 6 tahun 2014 tentang Desa. Adanya Undang-undang Nomor 6 tahun 2014 kini desa memiliki sumber penerimaan dana tambahan yaitu Dana Desa (DD), sebelumnya sumber penerimaan desa berasal dari Alokasi Dana Desa (ADD) dan bagi hasil pajak (PP Nomor 72 tahun 2005).

Dana Desa (DD) adalah dana yang bersumber dari Anggaran Pendapatan dan Belanja Negara (APBN) yang diperuntukan bagi desa dan desa adat yang ditransfer melalui Anggaran Pendapatan Belanja Daerah (APBD) kabupaten/kota dan digunakan untuk membiayai pembangunan, penyelenggaraan pemerintahan, serta pemberdayaan masyarakat. Tujuan awal Dana Desa (DD) ini diberikan untuk mengganti program pemerintah yang dulunya disebut Program Nasional Pembangunan Mandiri (PNPM). Dana Desa (DD) ini diharapkan dapat memicu terciptanya program-program yang bertujuan untuk lebih meningkatkan pembangunan dan pemberdayaan desa, untuk memperbaiki kondisi dan taraf hidup masyarakat dalam rangka pembangunan nasional demi tercapainya kesejahteraan yang adil dan merata.

Undang-undang Nomor 6 tahun 2014, pembangunan desa adalah upaya peningkatan kualitas hidup dan kehidupan untuk sebesar-besarnya kesejahteraan masyarakat desa dan pemberdayaan masyarakat desa. Pemberdayaan masyarakat desa merupakan upaya untuk mengembangkan kemandirian dan kesejahteraan masyarakat dengan peningkatan pengetahuan, sikap, keterampilan, perilaku, kemampuan, kesadaran, serta memanfaatkan sumber daya melalui penetapan kebijakan, progam, kegiatan, serta pendampingan yang sesuai dengan masalah dan prioritas kebutuhan masyarakat desa.

Upaya untuk mencapai masyarakat yang mandiri dan sejahtera tersebut pemerintah desa perlu memperhatikan implementasi tata kelola pemerintah yang baik (good governance). Menurut World Bank, good governance merupakan suatu penyelenggaraan manajemen pembangunan yang solid dan bertanggung jawab yang sejalan dengan prinsip-prinsip demokrasi. Pencapaian kemandirian tak lepas dari hubungan pemerintahan yang baik dan partisipasi masyarakat mendukung program-program pemerintah. Menurut Sedarmayanti (2003), good governance berarti menjunjung tinggi keinginan atau kehendak rakyat dan dapat meningkatkan kemampuan warga mencapai kemandirian, pembangunan berkelanjutan, serta keadilan sosial.

Menurut United Nation Development Program (UNDP), prinsip-prinsip good governance adalah partisipasi warga, kepastian hukum, transparansi, tanggung jawab (responsiveness), berorientasi konsensus, berkeadilan, efektifitas dan efisien, akuntabilitas, dan visi strategis. Prinsip good governance harus dapat diimplementasikan dalam penyelenggaraan pemerintah desa untuk mewujudkan pemerintahan yang baik. Penerapan 
prinsip-prinsip good governance menjadi sebuah keharusan hal ini terdapat dalam Permendagri Nomor 113 tahun 2014 bahwa asas pengelolaan keuangan desa berdasarkan asas transparansi, akuntabel, partisipatif serta dilakukan dengan tertib dan disiplin anggaran. Sejak tahun 2016 sampai tahun 2017 banyak terjadi kasus-kasus terhadap penyalahgunaan dan penyimpangan terhadap dana desa. Berdasarkan data dari Indonesia Corruption Watch (ICW) dalam wawancaranya yang diliput oleh Jambi Tribun News, "terdapat 100 kasus dana desa dan 102 kepala desa telah ditetapkan sebagai tersangka ditahun 2017'. Kebanyakan kasusnya berupa proyek fiktif dan markup anggaran. Penerapan good governance dalam pemerintahan desa atau nagari dapat mengurangi tindakan kecurangan dan penyimpangan terdapat anggaran desa tersebut.

Berdasarkan Peraturan Daerah Kabupaten Pesisir Selatan Nomor 2 tahun 2016 tentang Nagari menyatakan bahwa nagari adalah pemerintahan terdepan yang merupakan nama lain dari desa yang diakui dalam sistem pemerintahan Negara Kesatuan Republik Indonesia berdasarkan peraturan perundang-undangan. Pemerintahan nagari diwajibkan membuat Anggaran Pendapatan dan Belanja Nagari (APBNagari) untuk setiap tahun anggaran. Anggaran Pendapatan dan Belanja Nagari (APBNagari) yang berkualitas dan dikelola dengan baik dapat meningkatakan kemandirian dan kesejahteraan masyarakat.

Nagari Koto Nan Tigo Utara Surantih dan Nagari Koto Nan Tigo Selatan Surantih merupakan desa adat yang terletak di Kec. Sutera, Kab. Pesisir Selatan. Pada tahun 2016 nagari Koto Nan Tigo Utara Surantih merupakan desa mandiri di Kabupaten Pesisir Selatan sedangkan Nagari Koto Nan Tigo Selatan Surantih tidak dikategorikan sebagai desa yang mandiri. Nagari Koto Nan Tigo Utara Surantih sebagai desa yang mandiri diharapkan telah melaksanakan prinsip-prinsip good governance serta dapat mengelola Anggaran Pendapatan dan Belanja Nagari (APBNagari) lebih baik dari Nagari Koto Nan Tigo Selatan Surantih. Nagari Koto Nan Tigo Utara Surantih dan Nagari Koto Nan Tigo Selatan Surantih mendapatkan peneriman dana anggaran untuk kegiatan operasional pemerintah nagari yang cukup besar dan mengalami peningkatan tahun 2018.

Anggaran Pendapatan dan Belanja Nagari (APBNagari) merupakan bagian integral dari perangkat kebijakan pembangunan dan rumah tangga desa/nagari dalam mendukung pelaksanaan pembangunan untuk mencapai kesejahteraan dan kemandiriaan masyarakat. Dana anggaran yang begitu besar haruslah dikelola dengan baik dan diharapkan tidak terjadi penyalahgunaan angggaran. Namun dibalik dana anggaran yang besar terdapat indikasi kelemahan pada penerapan prinsip-prinsip good governance, pada kedua nagari tersebut seperti transparansi dalam pengelolaan keuangan masih kurang dan partisipasi atau keterlibatan masyarakat dalam pembentukan Rencana Kerja Pemerintah Nagari (RKP) yang masih minim. Partisipasi masyarakat merupakan salah satu faktor yang mempengaruhi keberhasilan dari program pembangunan maupun pengembangan masyarakat nagari, tanpa partispasi masyarakat program pembangunan akan sulit untuk dicapai. Partisipasi masyarakat bukan hanya melibatkan masyarakat dalam pengambilan keputusan di setiap program pembangunan, namun masyarakat juga dilibatkan dalam mengidentifikasi masalah dan potensi yang ada di masyarakat, karena keuangan desa adalah milik masyarakat desa, untuk masyarakat desa dan pada akhirnya dari desa untuk mencapai pembangunan nasional menjadi indonesia maju dan modern dimulai dan bertumpu.

Penelitian sebelumnya tentang desa banyak melakukan penelitian yang berfokus pada pengelolaan alokasi dana desa (Sumiati: 2015); analisis transparansi dan akuntabilitas pelaporan alokasi dana desa (Setiawan dan Anantawikrama: 2017); pengelolaan alokasi dana desa dalam pemberdayaan masyarakat desa (Putra: 2013); pengelolaan alokasi dana desa dalam menunjang pembangunan desa (Rosalinda: 2014). Penelitian lebih mendalam tetang desa ini diteliti oleh Artana (2013) tentang partisipasi masyarakat dalam penyusunan 
anggaran pendapatan dan belanja desa, dan penelitian oleh Mamelo (2017) tentang analisis pelaksanaan dan penatausahaan dana desa. penelitian sebelumnya yang belum banyak penelitian yang meneliti secara keseluruhan tentang sumber keuangan desa dan belum juga banyak peneliti yang melakukan penelitian tentang penerapan prinsip-prinsip utama good governance pada pengelolaan anggaran pendapatan dan belanja nagari.

Penelitian ini bertujuan untuk Mengetahui bagaimana pengelolaan Anggaran Pendapatan dan Belanja Nagari (APBNagari) di Nagari Koto Nan Tigo Utara Surantih dan Koto Nan Tigo Selatan Surantih, Kecamatan Sutera, Kabupaten Pesisir Selatan dan Mengetahui bagaimana implementasi good governance pada pengelolaan Anggaran Pendapatan dan Belanja Nagari (APBNagari) di Nagari Koto Nan Tigo Utara Surantih dan Koto Nan Tigo Selatan Surantih, Kecamatan Sutera, Kabupaten Pesisir Selatan.

\section{REVIU LITERATUR DAN HIPOTESIS}

\section{Teori Keagenan (Agency Theory)}

Teori keagenan telah dipergunakan secara luas di sektor privat maupun publik. Sektor publik, teori keagenan dipergunakan untuk menganalisis hubungan principals-agent dalam kaitannya dengan pengangggaran sektor publik (Latifah, 2010). Organisasi sektor publik bertujuan untuk memberikan pelayanan maksimal pada masyarakat atas sumber daya yang digunakan untuk kemakmuran dan kesejahteraan masyarakat.

Teori keagenan menganalisis susunan kontraktual diantara dua atau lebih individu, kelompok, atau organisasi. Salah satu pihak (prinsipal) membuat suatu kontrak, baik secara implisit maupun eksplisit dengan pihak lain (agent) dengan harapan agen akan bertindak atau melakukan pekerjaan seperti yang diinginkan oleh prinsipal. Kontrak atau kesepakatan yang dimaksud disini adalah pendelegasian wewenang kepada agen untuk melakukan semua pekerjaan secara bertanggungjawab. Pertanggungjawaban pemerintah atas pengelolaan anggaran desa kepada masyarakat desa (agent) sebagai pemberi amanah dalam pelaksanaan tugas pembangunan dan kesejahteraan masyarakat desa.

\section{Good Governance}

Menurut Koiman (1993), governance merupakan serangkaian proses interaksi sosial politik antara pemerintah dengan masyarakat dalam berbagai bidang yang berkaitan dengan kepentingan masyarakat dan intervensi pemerintah atas kepentingan-kepentingan tersebut. Governance diartikan sebagai mekanisme dan tata cara pemerintah dan masyarakat mengatur sumber daya untuk meningkatkan pembangunan sehingga tercapai kesejahteraan dan kemandirian di masyarakat.

Mardiasmo (2005) menyatakan bahwa orientasi pembangunan sektor publik adalah untuk menciptakan good governance, dimana dasarnya adalah tata kelola yang baik. Menurut United Nation Development Program (UNDP:2004), tata kelola pemerintahan yang baik adalah penggunaan wewenang ekonomi politik dan administrasi untuk mengelola berbagai urusan negara pada setiap tingkatannya dan merupakan instrumen kebijakan negara untuk mendorong terciptanya kondisi kesejahteraan integritas dan kohesivitas sosial dalam masyarakat. Menurut Sukasmanto (2004), untuk pengganggaran menjelaskan prinsip-prinsip good governance yang mempengaruhi adalah transparansi, akuntabilitas, partisipasi masyarakat, efisiensi dan efektivitas.

\section{Anggaran Pendapatan dan Belanja Nagari}

Berdasarkan Peraturan Daerah Kabupaten Pesisir Selatan Nomor 2 tahun 2016 tentang Nagari menyatakan bahwa nagari adalah pemerintahan terdepan yang merupakan nama lain dari desa yang diakui dalam sistem pemerintahan Negara Kesatuan Republik Indonesia 
berdasarkan peraturan perundang-undangan. Berdasarkan Peraturan Bupati Pesisir Selatan nomor 44 tahun 2017 tentang prioritas penggunaan dana nagari tahun angggaran 2018, menjelaskan bahwa Anggaran Pendapatan dan Belanja Nagari yang selanjutnya disebut APB Nagari adalah rencana keuangan tahunan pemerintahan nagari yang dibahas dan disetujui bersama oleh Pemerintahan Nagari dan BPD Nagari.

\section{METODE PENELITIAN}

Penelitian ini menggunakan jenis penelitian kualitatif dengan menggunakan paradigma interpretivisme. Penelitian interpretif bertujuan untuk mengembangkan sebuah konsep menjelaskan realitas, dan mengembangkan semacam pemahaman akan suatu masalah atau fenomena yang terjadi.

Penelitian ini dilakukan di nagari Koto Nan Tigo Utara Surantih dan Koto Nan Tigo Selatan Surantih, Kec. Sutera, Kab. Pesisir Selatan, Provinsi Sumatera Barat. Penelitian ini dilakukan agar dapat mengetahui bagaimana implementasi good governance dan pengelolaan Anggaran Pendapatan dan Belanja Nagari (APBNagari). Waktu penelitian ini yaitu dari bulan November 2018 sampai dengan bulan Februari 2019.

Jenis data adalah data primer. Data dikumpulkan melalui wawancara dengan mewawancarai 14 informan yang dilaksanakan dari bulan November 2018 sampai dengan Januari 2019. Jenis wawancara yang digunakan adalah semi-terstruktur yang dipandu dengan interview guide, selanjutnya demi meningkatkan akurasi dari pengumpulan data, wawancara akan direkam dengan seizin dari informan.

Teknik pengumpulan data yang digunakan adalah triangulasi. Teknik ini dipilih demi meningkatkan keterandalan data dan menangkap gambaran yang lebih mendalam mengenai analisis implementasi good governance pada pengelolaan anggaran pendapatan dan belanja nagari. Triangulasi yang digunakan yaitu triangulasi antar metode dan triangulasi antar informan.

\section{HASIL DAN PEMBAHASAN \\ Deskripsi Wilayah Penelitian}

Kabupaten pesisir selatan memiliki 15 kecamatan dan 182 nagari yaitu kecamatan Airpura, Bayang, Basa IV Balai Tapan, Batang Kapas, Koto XI Tarusan, Lengayang, Linggo Sari Baganti, Lunang, Pancung Soal, Ranah Ampek Balai, Ranah Pesisir, Silaut, Sutera, IV Jurai, dan IV Nagari Bayang. Kecamatan Sutera memiliki 12 nagari yaitu Taratak, Surantih, Amping Parak, Amping Parak Timur, Koto Taratak, Lansano Taratak, Aur Duri Surantih, Rawang Gunung Malelo Surantih, Koto Nan Tigo Selatan Surantih, Koto Nan Tigo Utara Surantih, Ganting Mudiak Selatan Surantih, dan Ganting Mudiak Utara Surantih.

\section{Pengelolaan APB Nagari pada nagari Koto Nan Tigo Utara Surantih dan Koto Nan} Tigo Selatan Surantih

Pengelolaan APB Nagari merupakan proses yang dimulai dari perencanaan APB Nagari, pelaksanaan APB Nagari, penatausahaan, pelaporan dan pertanggungjawaban pelaksanaan APB Nagari.

\section{Perencanaan APB Nagari pada Nagari Koto Nan Tigo Utara Surantih dan Koto Nan Tigo Selatan Surantih}

Berdasarkan hasil wawancara pada nagari Koto Nan Tigo Utara Surantih dan Koto Nan Tigo Selatan Surantih bahwa proses perencanaan dan penganggaran APB Nagari dimulai dari ditetapkannya RPJM Nagari. Penetapan RPJM Nagari dimulai dari rembuk kampung untuk menggali ide-ide dan gagasan dari masyarakat atau usulan-usulan untuk kegiatan pemerintahan nagari selama 6 tahun kedepan, setelah itu pemeritahan nagari 
mengadakan Musyawarah Nagari (Musnag) bersama masyarakat untuk menentukan atau memilih kegiatan-kegiatan atau usulan-usulan dari rembuk kampung untuk di masukan kedalam rancangan RPJM, setelah rancangan RPJM dibuat pemerintahan nagari mengadakan musrembang RPJM untuk menetapkan RPJM Nagari bersama pemerintahan kecamatan, Bamus nagari dan Masyarakat nagari setempat. Hal ini sesuai dengan hasil wawancara sebagai berikut:

"Sebelum RPJM dibuat, kami mengadakan rembuk kampung, guna menggali ideide dari masyarakat untuk dimasukan ke RPJM, setelah itu baru diadakan musrembang RPJM pada september 2018 sama-sama kita melakukan rapat dengan menghadirkan camat, tokoh masyarakat dan kapolsek beserta orang-orang yang telah ditetapkan.’(Bpk. Wali nagari Koto Nan Tigo Selatan Surantih).

Pemerintahan nagari Koto Nan Tigo Utara Surantih juga melakukan hal sama dalam proses penetapan RPJM Nagarinya. Hal ini sesuai dengan hasil wawancara sebagai berikut:

"Sebelum penetapan RPJM Nagari, pemerintahan nagari melaksanakan rembuk kampung untuk menggali ide dan gagasan dari masyarakat,selanjutnya ide dan gagasan di input oleh tim yang dibentuk oleh pemerintahan, setelah itu pemerintahan nagari melakukan musrembang nagari yang dihadiri oleh unsur lapisan masyarakat seperti tokoh masyarakat, niniak mamak, bundo kanduang, dan generasi muda."(Bpk. Wali nagari Koto Nan Tigo Utara Surantih).

RPJM Nagari untuk periode 2018-2024 Koto Nan Tigo Utara Surantih dan Koto Nan Tigo Selatan Surantih sudah ditetapkan, Koto Nan Tigo utara Surantih waktu penetapan RPJM sudah sesuai dengan Permendagri 20 tahun 2018 yaitu pada tgl 24 agustus 2018, tepat 3 bulan setelah dilantiknya wali nagari pada bulan mei 2018. Nagari Koto Nan Tigo Selatan Surantih terlambat dalam penetapan RPJM namun dalam waktu tenggang penetapannya yaitu pada awal bulan september 2018. Hal ini dibuktikan dengan hasil wawancara sebagai berikut:

“Untuk RPJM ditetapkan bulan agustus 2018.”( Bpk. Wali nagari Koto Nan Tigo Utara Surantih)

Nagari Koto Nan Tigo Selatan Surantih terlambat dalam penetapan RPJM berdasarkan Permendagri Nomor 20 tahun 2018 yaitu pada awal bulan september, tetapi berdasarkan ketetapan dari Pemeritah Kabupaten Pesisir Selatan masih dalam waktu yang ditetapkan yaitu paling lambat bulan september. Hal ini sesuai dengan hasil wawancara sebagai berikut:

"Ditetapkan setelah pelantikan wali nagari pada bulan mei 2018, dan RPJM nagari koto nan tigo selatan surantih ko bulan september 2018."(Sekretaris wali nagari Koto Nan Tigo Selatan Surantih).

Dalam penyusunan RPJM Nagari, tim penyusun melakukan penyelarasan dengan arah kebijakan pembangunan kabupaten untuk mengintegrasikan program pembangunan kabupaten dengan pembangunan nagari. Pada nagari Koto Nan Tigo Utara Surantih dan Koto Nan Tigo Selatan Surantih sudah melakukan penyelarasan antara rencana 
pembangunan kabupaten dengan rencana pembangunan nagari. Hal ini sesuai dengan wawancara sebagai berikut:

"Iya, disaat melakukan RPJM nagari melakukan koordinasi dengan pemerintahan kecamatan dan kabupaten.”(Wali nagari Koto Nan Tigo Utara Surantih).

"Iya, kita di nagari harus berkoordinasi dengan pemerintah kabupaten.”(Bpk. Wali nagari Koto Nan Tigo Selatan Surantih).

Setelah selesai penyusunan RPJM, Pemerintah Nagari kemudian menyusun Rencana Kerja Pemerintah (RKP) Desa yang memiliki jangka waktu 1 (satu) tahun. RKP ini merupakan penjabaran dari RPJM. Penyusunan RKP pada nagari Koto Nan Tigo Selatan Surantih dilakukan melalui Musrenbang yang diwakili oleh perwakilan-perwakilan masyarakat Nagari, namun sebelum dilakukan Musrembang RKP pemerintahan nagari melakukan Musnag untuk menentukan kegiatan-kegiatan yang akan dijadikan prioritas untuk dimasukan kedalam rancangan RKP yang akan dibawah ke Musrembang RKP. Hal ini sesuai dengan hasil wawancara sebagai berikut:

"Iya, RKP dibentuk setelah RPJM. Sebelum RKP ini ditetapkan, kami di nagari melakukan musnag untuak memutuskan apa saja kegiatan yang akan dimasukan kedalam RKP, setelah itu baru diadakan musrembang”(Bpk. Wali nagari Koto Nan Tigo Selatan Surantih).

Nagari Koto Nan Tigo Utara Surantih juga melakukan hal yang sama dalam penetapan RKP Nagarinya, sebelum penetapan RKP Nagari nagari Koto Nan Tigo Utara Surantih terlebih dahulu melakukan musnag untuk memilih kegiatan yang ada di RPJM Nagari untuk dimasukan kedalam RKP Nagari. Hal ini sesuai dengan hasil wawancara sebagai berikut:

"Setelah RPJM tadi ditetapkan, maka kami di nagari menetapkan RKP nagari. Sebelum penetapan RKP nagari melakukan kan dulu musnag untuk menentukan rencana pembangunan yang akan dijadikan prioritas, setelah itu baru diadakan musrembang RKP untuk menetapkan RKP dengan Bamus, masyarakat, dan utusan dari kecamatan. RKP untuk tahun 2019 kami tetapkan november 2018."(Wali nagari Koto Nan Tigo Utara Surantih).

Tahapan setelah RKP Nagari ditetapkan maka pemerintah nagari membuat Rancangan APB Nagari, dan dibahas dalam musyawarah dengan BAMUS Nagari untuk disepakati. Rancangan APB Nagari ini paling lambat ditetapkan bulan oktober tahun bejalan. Selanjutnya pemerintah nagari menyampaikan Rancangan APB Nagari kepada Wali kota/ Bupati melaului Camat untuk dievaluasi, paling lambat 3 hari sejak disepakatinya RKP Nagari. Rancangan APB Nagari yang telah dievaluasi maka Wali nagari menetapkan Rancangan APB Nagari menjadi Peraturan Nagari tentang APB Nagari, penetapan ini paling lambat per 31 desember tahun anggaran sebelumnya. Nagari Koto Nan Tigo Utara Surantih dan Koto Nan Tigo Selatan Surantih dalam hal ini sampai tanggal 15 januari 2019 pada saat peneliti melakukan penelitian, pemerintahan nagari belum bisa membuat APB Nagari atau Rancangan APB Nagari dikarenakan peraturan dari kabupaten belum diterima pemerintahan nagari. Hal ini dibuktikan dari hasil wawancara sebagai berikut: 
"Ini lah Kendala kami di nagari, dalam menyusun APB Nagari ini dibutuhkan peraturan dari kabupaten, peraturan dari kabupaten itu sendiri yang belum terbit sampai saat ini, kami menunggu peraturan itu kami terima"(sekretaris wali nagari Koto Nan Tigo Utara Surantih).

"Belum ditetapkan, menunggu perbup keluar dulu."(Wali nagari Koto Nan Tigo Selatan Surantih).

Tahapan dalam penyusunan APB Nagari tahun anggaran 2018 yang lalu nagari Koto Nan Tigo Utara Surantih dan Koto Nan Tigo Selatan Surantih dilakukan setelah RKP Nagari ditetapkan pemerintahan nagari menyusun Rancangan APB Nagari dengan berpedoman pada RKP Nagari serta RAB pada RKP Nagari, setelah Rancangan APB Nagari selesai, Wali nagari atau Sekretaris wali nagari menyampaikannya ke Bamus untuk dikorekasi dan ditetapkan sebagai Peraturan Nagari tentang APB Nagari. Hal ini sesuai dengan hasil wawancara sebagai berikut:

"Setelah RKP Nagari ditetapkan baru nagari membuat Rancangan APB Nagari, semua kegiatan yang ada di APB nanti harus ada di RKP, Rancangan APB Nagari dibuat setelah peraturan dari Bupati diterima, Rancangan ini nantinya disampaikan ke Bamus nagari untuk dibahas dan disahkan sebagai Pernag tentang APB Nagari, tahapan selanjutnya APB Nagari tadi disampaikan ke Bupati melalui camat."(Sekretaris wali nagari Koto Nan Tigo Utara Surantih).

“APB Nagari biasanya kami buat setelah RKP Nagari ditetapkan, lalu kami di nagari menuyusun Rancangan APB Nagari yang di koordinir oleh sekretaris, setelah itu kami serahkan ke Bamus untk ditetapkan jadi Pernag tentang APB Nagari."(Wali nagari Koto Nan Tigo Selatan Surantih).

Keterlambatan penetapan APB Nagari tersebut berdanpak pada terlambatnya kegiatan yang ada pada APB Nagari untuk dilaksanakan, operasional kantor terhambat, dan gaji pegawai belum bisa dibayarkan. Hal ini buktikan dari hasil wawancara sebagai berikut:

"Resiko di nagari ya itu, gaji nunggak, operasional kantor di tanggulangi dulu. Kegiatan pastinya terlambat juga"(Sekretaris wali nagari Koto Nan Tigo Selatan Surantih).

"Gaji tidak bisa diterima, kegiatan diundur, untuk biaya kantor di tanggulangi dulu."(Wali nagari Koto Nan Tigo Utara Surantih).

\section{Pelaksanaan APB Nagari dan Penatausahaan}

Tahap Pelaksanaan APB Nagari dan penatausahaan pada pemerintahan nagari dilaksanakan oleh Bendahara nagari untuk mencatat semua penerimaan atas pendapatan nagari dan pengeluaran belanja atas beban APB Nagari dan didukung oleh bukti yang sah serta di otorisasi oleh Kaur Keuangan dan Wali nagari dan dilaksanakan melalui rekening kas nagari yang sudah ditetapkan oleh Bupati. Nagari Koto Nan Tigo Utara Surantih dan Koto Nan Tigo Selatan Surantih sudah melaksanakannya, hal tersebut sesuai dengan hasil wawancara sebagai berikut: 
"Semua penerimaan dan pengeluaran nagari kami laksanakan pada rekening nagari. Di otorisasi Bendahara dan Wali nagari."(Bendahara nagari Koto Nan Tigo Utara Surantih).

"Iya. semua penerimaan dan pengeluaran dilaksanakan pada rekening nagari. Di otorisasi Bendahara dan Pak Wali nagari."(Bendahara nagari Koto Nan Tigo Selatan Surantih).

Penerimaan dan pengeluaran terhadap APB Nagari dicatat pada Buku Kas Umum. Bendahara nagari juga wajib membuat buku pembantu kas umum yang terdiri atas buku pembantu bank (mencatat penerimaan dan pengeluaran melalui rekening nagari), Buku Pembantu Pajak (mencatat penerimaan potongan pajak dan pengeluaran setoran pajak), dan Buku Pembantu Panjar (mencatat pemberian dan pertanggungjawaban panjar). Buku kas umum wajib dilaporkan oleh Bendahara kepada Wali nagari setiap bulannya, paling lambat tanggal 10 bulan berikutnya. Nagari Koto Nan Tigo Utara Surantih dan Koto Nan Tigo Selatan Surantih sudah menerapkannya, namun untuk Buku Pembantu panjar belum dilaksanakan untuk kegiatan tahun anggaran 2018, Buku Pembantu panjar dilkasanakan di tahun 2019 karena Permendagri 20 tahun 2018 berlakunya untuk kegiatan pemerintahan nagari/desa tahun anggaran 2019 sesuai dengan hasil wawancara sebagai berikut:

"Ada 3 macam buku pencatatan yang saya catat, yaitu buku kas umum, buku kas pembantu bank, buku kas pembantu pajak, buku kas pembantu panjar. Setiap awal bulan memberikan laporan kepada Wali nagari melalui Sekretaris."(Bendahara nagari Koto Nan Tigo Utara Surantih).

“Ada buku kas umum, buku kas untuk bank, buku kas pajak. Setiap akhir bulan atau awal bulan wajib lapor kepada Wali nagari."(Bendahara nagari Koto Nan Tigo Selatan Surantih).

Dari hasil wawancara diatas nagari Koto Nan Tigo Utara Surantih telah melaksanakan tahapan pelaksanaan APB Nagari dan penatausahaan yang sesuai dengan Permendagri Nomor 20 tahun 2018. Dari hasil wawancara diatas disimpulkan bahawa buku panjar belum diterapkan karena kegiatan di tahun 2018 mengacu pada Permendagri Nomor 113 tahun 2014 dan Permendagri 20 dilaksanakan untuk pelaksanaan pemerintahan yang berkaitan dengan periode anggaran tahun 2019 sampai 2024.

\section{Pelaporan dan Pertanggungjawaban pelaksanaan APB Nagari}

Pemerintahan nagari dalam halini Wali nagari diwajibkan membuat laporan atas pelaksanaan APB Nagari setiap tahunnya berupa laporan semester pertama dan laporan akhir tahun anggaran. Laporan semester pertama dilaporkan oleh Wali nagari kepada Bupati melalui Camat paling lambat pada minggu kedua bulan juli tahun berjalan dan laporan akhir tahun paling lambat disampaikan 3 bulan setelah akhir tahun anggaran. Laporan semester dan laporan akhir tahun diinformasikan kepada masyarakat melalui media informasi, laporan tersebut memuat laporan realisasi APB Nagari, laporan realisasi kegiatan, sisa anggaran dan alamat pengaduan. Nagari Koto Nan Tigo Utara surantih dan Koto Nan Tigo Selatan Surantih telah melaksanakan pelaporan dan pertanggungjawaban tersebut.

Nagari Koto Nan Tigo Utara surantih dan Koto Nan Tigo Selatan Surantih menyampaikan laporan semester pertama ke kabupaten pada bulan juli dan laporan akhir tahun pada awal bulan tahun anggaran berikutnya. Hal tersebut sesuai dengan hasil wawancara sebagai berikut: 
"Wali nagari wajib melaporkan semester pertama dan semester kedua ke Kabupaten. Laporan semester pertama pada bulan juli dan laporan akhir tahun biasanya januari."(Wali nagari Koto Nan Tigo Utara Surantih).

"iya, ada laporan semester pertama bulan juli, laporan semester kedua akhir tahun di desember atau januari."(Wali nagari Koto Nan Tigo Selatan Surantih).

Nagari Koto Nan Tigo Utara Surantih menyampaikan realisasi APB Nagari dan pelaksanaan APB Nagari kepada masyarakat melalui lisan dan media tertulis berupa baliho dan di papan pengumuman. Hal ini sesuai dengan hasil wawancara sebagai berikut:

"Realisasi APB Nagari disampaikan melalui media tertulis seperti spanduk dan papan pengumuman di kantor wali nagari dengan rincian-rincian yang jelas."(Wali nagari Koto Nan Tigo Utara Surantih).

Nagari Koto Nan Tigo Selatan Surantih menyampaikan realisasi pelaksanaan APB Nagari dalam bentuk baliho, spanduk dan di papan pengumuman. Hal ini sesuai dengan hasil wawancara sebagai berikut:

“Ada, dalam bentuk tertulis, baliho di depan kantor itu."(Wali nagari Koto Nan Tigo Selatan Surantih).

\section{Implentasi Good Governance pada pengelolaan APB Nagari}

Implementasi good governance pada pengelolaan APB Nagari menjadi sangat penting untuk dilakukakan oleh pemerintahan nagari demi tercapainya kesejahteraan dan kemandirian nagari. Pembangunan yang berlandaskan prinsip-prinsip good governance diharapkan dapat terwujudnya program-program pembangunan desa yang berkualitas untuk meningkatkan pemberdayaan desa serta diharapkan dapat mengurangi tindakan-tindakan kecurangan yang dapat merugikan negara demi tercapainya pembangunan nasional untuk Indonesia maju. Implementasi good governance pada pengelolaan APBN Nagari adalah sesuatu yang menjadi keharusan hal ini sesuai dengan Permendagri Nomor 20 tahun 2018 bahwa pengelolaan keuangan desa harus dikelola berdasarkan asas transparansi, partisipatif, akuntabel, serta dilakukan dengan tertib dan disiplin anggaran. Menurut Sukasmanto (2004), untuk pengganggaran menjelaskan prinsip-prinsip good governance yang mempengaruhi adalah transparansi, akuntabilitas, partisipasi masyarakat, efisiensi dan efektivitas.

\section{Implementasi prinsip Partisipasi masyarakat}

Setiap orang atau warga negara memiliki hak suara yang sama dalam proses pengambilan keputusan, baik secara lansung maupun lembaga perwakilan, sesuai dengan kepentingan dan aspirasi masing-masing. Partisipasi yang luas ini perlu dibangun dalam suatu tatanan kebebasan berserikat dan berpendapat, serta kebebasan untuk berpartisipasi secara konstruktif.

Partisipasi pada pengeloalan APB Nagari bermakna bahwa masyarakat memiliki suara dalam pembentukan keputusan, penyusunan anggaran, ikut dalam pengambilan keputusan dalam menyusun RPJM Nagari dan RKP Nagari serta bentuk lain peran aktif masyarakat dalam kegiatan pemerintahan nagari.

Masyarakat nagari Koto Nan Tigo Utara Surantih dan Koto Nan Tigo Selatan Surantih memiliki peran penting dalam kegiatan pemerintahan nagari. Masyarakat tidak 
hanya dilibatkan dalam pengambilan keputusan tentang RKP dan RPJM Nagari tetapi masyarakat dilibatkan dalam pengawasan serta berperan aktif dalam mendorong pembangunan dalam bentuk swadaya masyarakat seperti gotong royong, dan memberi izin lahan dalam pembangunan nagari. Hal ini sesuai dengan hasil wawancara sebagai berikut:

"Masyarakat ikut dalam musrembang dan rembuk kampung untuk menentukan RPJM dan RKP, Masyarakat juga ikut mengawasi, baik kerja fisik ataupun pemberdayaan.”(Wali nagari Koto Nan Tigo Utara Surantih).

"Masyarakat ikut dalam musyawarah di nagari, gotong royong, dan pengawasan dana desa ini."(Wali nagari Koto Nan Tigo Selatan Surantih).

\section{Implementasi prinsip Akuntabilitas dan Transparansi}

Akuntabilitas merupakan pertanggungjawaban pemerintahan nagari kepada pemberi amanah yaitu pemerintahan kabupaten dan masyarakat nagari setempat. Pertanggungjawaban akan suatu kegiatan harus dilaksanakan untuk mengembalikan kepercayaan masyarakat kepada pemerintah. Pemerintahan nagari pada pengelolaan angggaran pendapatan dan belanja nagari, semua belanja dan penggunaan anggaran lainya harus dapat dipertanggungjawabkan oleh pemerintah desa/nagari serta trasparan dalam pelaksanaanya. Transparansi disini adanya kebebasan dan kemudahan masyarakat untuk memperoleh informasi tentang penyelenggaraan pemerintahan nagari dalam bentuk adanya pusat informasi, papan pengumuman, media cetak dan lain-lain.

Nagari Koto Nan Tigo Utara Surantih telah menerapkan prinsip akuntabilitas berupa adanya pertangungjawaban kepada pemerintahan kabupaten dan kepada masyarakat pada forum musyawarah. Prinsip transparansi yang dilaksanakan pemerintahan nagari Koto Nan Tigo Utara Surantih dalam bentuk media tertulis seperti adanya plang pelakasanaan APB Nagari dengan rincian anggarannya, adanya baliho realisasi APB Nagari, serta kegiatankegiatan pemerintah nagari pada papan pengumuman. Hal ini dibuktikan dengan hasil wawancara sebagai berikut:

"Pelaksanaan APB Nagari diisampaikan secara tertulis melaluli plang-plang di proyek. secara lisan disampaikan dalam forum musyawarah, biasanya di mesjid, sebelum musyawarah nagari."(Sekretaris wali nagari Koto Nan Tigo Utara Surantih).

Nagari Koto Nan Tigo Selatan Surantih dalam menerapkan prinsip akuntabilitas dan transparansinya dalam bentuk spanduk dan baliho, dan disampaikan kepada masyarakat dalam bentuk tim yang sudah dibentuk yaitu tim PPHP pada saat musrembang. Hal ini dibuktikan dengan hasil wawancara sebagai berikut:

"Iya. Sabenarnya diawal tahun atau akhir pemerintahan nagari membuat laporan realisasi kegiatan pemerintah nagari satu tahun. Di nagari kita wajib membuat realisasi APB Nagari dalam bentuk baliho, karena kita di nagari keterbatasam media, dan papan informasi. Pada saat musremabang kami di nagari menyampaikan pelaksanaan kegiatan nagari kapada tim PPHP yang dibentuk dari masyarakat sebagai perwakilan dari masyarakat."(sekretaris wali nagari Koto Nan Tigo Selatan Surantih). 


\section{Implementasi prinsip Efisiensi dan Efektivitas}

Efisiensi dan efektivitas menyangkut setiap proses kegiatan dan kelembagaan diarahkan untuk menghasilkan sesuatu yang benar-benar sesuai dengan kebutuhan melalui pemanfaatan yang sebaik-baiknya dari berbagai sumber yang tersedia. Pemerintahan nagari dalam menerapkan prinsip efisien dan efektivitas ini berupa kegiatan-kegiatan yang ada dalam RKP Nagari yang dibiayai pada APB Nagari memang sesuai dengan kebutuhan masyarakat saat itu, dan dianggarkan dengan anggaran yang wajar sesuai dengan standard biaya yang diatur oleh peraturan bupati. Pada saat pelaksanaan kegiatan yang ada dalam RKP dan APB Nagari pemerintahan nagari membuat rincian yang sesuai dengan pengeluaran pada pelaksanaan tersebut dan disertai dengan bukti yang sah. Nagari Koto Nan Tigo Utara Surantih dalam menentukan kegiatan yang sesuai dengan kebutuhan masyarakat nagari atau yang akan dijadikan prioritas mengacu pada dua pertimbangan yaitu asas manfaat dan kepentingan. Anggaran pada setiap kegiatan tersebut menggunakan Standard Biaya Umum (SBU) yang diterima dari pemerintahan kabupaten. Hal ini sesuai dengan hasil wawancara sebagai berikut:

“Dalam RKP dan APB Nagari menggunakan SSH dan SBU tersebut."(Sekretaris wali nagari Koto Nan Tigo Utara Surantih).

"Sudah ada peraturan dari kabupaten tentang harga tersebut, jadi kami berpatokan dari peraturan tersebut."(Wali nagari Koto Nan Tigo Selatan Surantih).

Nagari Koto Nan Tigo Selatan Surantih menetapkan kegiatan pemerintahan nagari yang akan dijadikan prioritas dengan mempertimbangkan kelayakan dan manfaatnya. Kegaiatan dalam RKP atau APB Nagari dalam menentukan anggaran biayanya memakai standard harga adari kabupaten. Hal ini sesuai dengan hasil wawancara sebagai berikut:

"Proyek atau kegiatan nagari daijadikan prioritas berdasarkan musyawarah dengan masyarakat, dan dilihat kebermanfaatan kalau manfaatnya banyak itu segera dijadikan prioritas...”(Wali nagari Koto Nan Tigo Utara Surantih).

"Tergantung kepada masyarakat, dan menyangkut pembebasan lahan, jika masyarakat memberikan izin lahan maka kegiatan atau proyek tersebut dijadikan prioritas."(Wali nagari Koto Nan Tigo Selatan Surantih).

\section{SIMPULAN, KETERBATASAN DAN SARAN \\ Simpulan}

Berdasarkan penelitian yang telah dilakukan, maka penulis menyimpulkan sebagai berikut:

1. Pengelolaan APB Nagari pada Koto Nan Tigo Utara Surantih dan Koto Nan Tigo Selatan Surantih berdasarkan Permendagri Nomor 20 tahun 2018 tentang Pengelolaan Keuangan Desa terdapat permasalahan pada tahap perencanaan. Nagari Koto Nan Tigo Selatan Surantih terlambat dalam Penetapan RPJM Nagari dan APB Nagari dan Nagari Koto Nan Tigo Utara Surantih hanya terlambat dalam penetapan APB Nagari. Terlambatnya penetapan APB Nagari dikarenakan lamanya peraturan dari kabupaten ke nagari dikeluarkan. Tahapan penatausahaan, pelaporan dan pertanggungjawaban sudah sesuai dengan Permendagri Nomor 20 Tahun 2018 tentang Pengelolaan Keuangan Desa.

2. Implementasi prinsip-prinsip Good Governance pada pengelolaan APB Nagari pada nagari Koto Nan Tigo Utara Surantih dan Koto Nan Tigo Selatan Surantih sudah dilaksanakan cukup baik oleh pemerintah nagari. 
a. Prinsip partisipasi diterapkan dalam bentuk adanya masyarakat ikut dalam menentukan RPJM Nagari dan RKP nagari, mulai dari rembuk kampung,musnag dan musremabng RKP dan RPJM serta ikut dalam swadaya dan pengawasan pelaksanaan APB Nagari.

b. Prinsip akuntabilitas dan transparansi dalam bentuk adanya realisasasi pelaksanaan dan APB Nagari di sampaikan kepada masyarakat dalam forum musyawara, spanduk, baliho, dan pada papan pengumuman yang mudah di akses masyarakat

c. Prinsip efisiensi dan efektivitas dalam bentuk, pemerintahan nagari dalam menetukan kegiatan yang akan di sahkan dalam RKP Nagari dibahas dengan mempertimbang kelayakan, kemanfaatan, dan kepentingan serta setiap rencana kegiatan tersebut telah disertai dengan standard harga yang dia atur dari peraturan kabupaten.

\section{Saran Untuk Penelitian Selanjutnya}

Untuk penelitian selanjutnya, sebaiknya dilakukan 3 bulan setelah tahun anggaran sehingga proses tahapan pengelolaan APB Nagari telah selesai dilaksanakan dan pemerintahan nagari lebih memiliki waktu yang baik untuk memberikan informasinya. Untuk penelitian selanjutnya dapat dilakukan pada nagari dengan kecamatan yang berbeda-beda, Kabupaten yang berbeda dan memiliki kultur budaya yang berebeda sehingga didapatkan hasil yang lebih menarik.

\section{DAFTAR PUSTAKA}

Artana, I Made Adi, dkk. 2013. "Partisipasi Masyarakat dalam Penyusunan Anggaran Pendapatan Belanja Desa (APBDes) di Desa Sumerta Kaja, Kecamatan Denpasar Timur". Jurnal

Koiman, J., (ed). 1993.Moderen Governance: New Government-Society Interactions. London: Sage Publications.

Latifah, N.P. 2010. "Adakah Perilaku Oportunistik dalam Aplikasi Agency Theory di Sektor Publik?”. Fokus Ekonomi. Vol. 5 No. 2

Mamelo, Yunius Rainal, dkk. 2016. Analisis Pelaksanaan dan Peanatausahaan Dana Desa. $e$ journal Unsrat, Vol: 7 No: 22016

Mardiasmo. 2005. Akuntansi Sektor Publik. Yogyakarta:Andi Yogyakarta. 2010. Otonomi dan Manajemen Daerah. Penerbit Andi. Yogyakarta.

Peraturan Bupati Pesisir Selatan nomor 44 tahun 2017 tentang prioritas penggunaan dana nagari tahun angggaran 2018.

Peraturan Daerah Kabupaten Pesisir Selatan nomor 2 tahun 2016 tentang Nagari

Peraturan Pemerintah Nomor 72 tahun 2005 tentang Desa

Permendagri Nomor 20 Tahun 2018 tentang pengelolaan keuangan desa

Putra, Chandra Kusuma, dkk. 2013. "Pengelolaan Alokasi Dana Desa dalam Pemberdayaan Masyarakat Desa (Studi pada Wonorejo Kecamatan Singosari Kabupaten Malang)". Jurnal Administrasi Publik (JAP), 1203-1212.

Rosalinda, Okta. 2014. "Pengelolaan Alokasi Dana Desa (ADD) dalam Menunjang Pembangunan Pedesaan". Jurnal Ilmiah Fakultas Ekonomi dan Bisnis Universitas Brawijaya Malang.

Sedarmayanti. 2003. Good Governance (kepemerintahan Yang Baik) Dalam Rangka Otonomi Daerah. Bandung: Mandar Maju

Setiawan, Made Wiradarma, dkk. 2017. "Analisis Transparansi dan Akuntabilitas Pelaporan Alokasi Dana Desa". e-journal Universitas Pendidikan Genesha, Vol: 7 No:1 Tahun 2017. 
Sujarweni, V. Wiratna. 2015. Akuntansi Desa Panduan Tata Kelola Keuangan Desa.Yogyakarta: Pustaka Baru Press

Sukasmanto, dkk. 2004. Promosi Otonomi Desa. Yogyakarta: IRE Press

Sumiati. 2015. "Pengelolaan Alokasi Dana Desa pada Desa Ngatabaru Kecamatan Sigi Biromaru Kabupaten Sigi”. e-Jurnal Katalogis, 135-142.

Tribun Jambi. 2018. http://jambi.tribunnews.com/2018/03/20/icw-sebut-angka-korupsidana-desa-naik-di-2018-sudah-102-kades-tersangka. Diakses 16 oktober 2018.

Undang-undang Nomor 6 tahun 2014 tentang Desa.

Undang-Undang Nomor 8 tahun 2005 tentang perubahan atas Undang-undang Nomor 32 tahun 2004 Tentang Pemerintah Daerah.

UNDP. 2004. Human Development Report. New York : Oxford Univesity Press.

Walidin, Warul., dkk. 2015. Metodologi Penelitian Kualitatif \& Grounded Theory. Banda Aceh: FTK Ar-Raniry Press.

World Bank. "A definition of e-Government": Diakses pada www.worldbank.org/publicsector/egov/definition.htm. 05 Agustus 2018 